\title{
The Rise of English Among K-Pop Idols: Language Varieties in The Immigration
}

\author{
$1^{\text {st }}$ Andita Dyah Octaviani \\ English Studies Program, Faculty \\ of Humanities \\ Universitas Indonesia, \\ Depok, Indonesia \\ andita.dyah@ui.ac.id
}

\author{
$2^{\text {nd }}$ Harumi Manik Ayu Yamin* \\ Linguistics Department, Faculty of \\ Humanities \\ Universitas Indonesia, \\ Depok, Indonesia \\ harumi.m@ui.ac.id
}

\begin{abstract}
Well known worldwide, K-Pop idols are expected to maintain their fame by speaking in English to promote themselves to international viewers. The idea that K-Pop idols ought to speak English is even emphasized by the host of a variety show called The Immigration, aired on K-Style TV. The host has stated that speaking English is essential for K-Pop idols before they attend any overseas performances. Nonetheless, some K-Pop idols are still unaccustomed to English, which leads to the phenomena called code-switching and code-mixing. To explore this matter, this study used three episodes of The Immigration to determine the influential factors behind the code-switching and codemixing phenomena. Moreover, this study used a questionnaire that was filled out through Google Forms to gather opinions from international viewers after watching the show. The result shows that K-Pop idols tend to switch and mix their languages to maintain topics and solidarity among the group members. Furthermore, the survey shows that the perception from participants of both sex groups toward K-Pop idols may vary due to their sense of belonging to the K-Pop fandom.
\end{abstract}

Keywords - code-switching, code-mixing, K-Pop idols, international fans, Korean-English.

\section{Introduction}

Korean pop, or K-Pop, is a music genre that has been spreading all around the world, not only in Asian countries but also in non-Asian countries. Society today is aware of the diversity of K-Pop groups, whether in the form of male groups or female groups. As K-Pop idols have the goal of stealing the spotlight by attracting more people in non-Asian countries, they have been attempting to communicate with global fans using an international language, which is English. Whether they speak a simple word or a simple sentence, most K-Pop idols today put effort into talking with their fans using English rather than Korean. It turns out that using English in conversation makes the fans, especially international fans, feel more attracted to K-Pop idols because they can comprehend them better.

When it comes to speaking English, K-Pop idols cannot avoid two phenomena in sociolinguistics studies: code-switching and code-mixing. These two phenomena occur when speakers switch and mix languages during dialog with their interlocutor without changing the context or meaning of their utterances [1]. Code-switching and code-mixing have developed into common phenomena in society, especially in bilingual and multilingual countries. Stylianou-Panayi [2] acknowledges that code-switching and codemixing may occur in bilingual communities. Owen [3] mentions that South Korean citizens use several languages daily, such as standard Korean, Korean dialects, English, Chinese, and Japanese.

This research paper has two essential aims: to investigate the influential factors that affect K-Pop idols to switch and mix their speech between English and Korean and to investigate viewers' opinions toward the phenomenon that leads to the impact of using English as the choice of language for nonKorean viewers. A Korean variety show aired on $\mathrm{K}$ Style TV called The Immigration is the main corpus of this research paper. The Immigration is about K-Pop idols who become guest stars in one of the largest KPop concerts called K-Con so that they get invited to The Immigration. K-Con [4] was established in 2012 and first began in Irvine, California. CJ E\&M, the production that organizes the concert, has the aim of allowing people all around the world to experience the Korean culture.

During The Immigration, K-Pop idols are expected to communicate in English as much as possible to test their English ability before they go to the country where K-Con will take place. In the middle of their conversations, most K-Pop idols cannot avoid codeswitching and code-mixing between Korean and English. Interestingly, one of the hosts mentions that to be able to communicate with international fans, speaking English is very important for K-Pop idols. Furthermore, to determine viewers' opinions toward this phenomenon, this research paper only focuses on a mini-survey that was conducted to analyze people's comments about the importance of English for K-Pop Idols, along with the impact of code-switching and code-mixing on the viewers, whether they are fans of K-Pop or not.

\section{Method}

This research paper was conducted to answer two questions regarding the topic of English as the language choice in code-switching and code-mixing that occur in K-Pop Idols' conversations. The questions this research paper attempts to investigate are: 
Research question 1: What are the aspects that influence the occurrence of the code-switching and code-mixing phenomena in K-Pop Idols' conversation in The Immigration?

Research question 2: How does the use of English attract viewers of The Immigration, despite the frequent use of code-switching and code-mixing during the show?

In this research, there are two types of participants: those in the video K-STYLE TV: The Immigration [5] [6] [7] [8] and those who filled out the survey through the Google Forms.

\begin{tabular}{|c|c|c|c|c|}
\hline No & Name & DOB & Nationality & Occupation \\
\hline 1 & $\begin{array}{l}\text { Kim } \\
\text { Myungjun } \\
(\mathrm{MJ})\end{array}$ & $\begin{array}{l}\text { March 5, } \\
1994\end{array}$ & Korean & $\begin{array}{l}\text { Singer of } \\
\text { ASTRO }\end{array}$ \\
\hline 2 & $\begin{array}{l}\text { Lee Dabin } \\
\text { (Yeonwoo) }\end{array}$ & $\begin{array}{l}\text { August 1, } \\
1996\end{array}$ & Korean & $\begin{array}{l}\text { Singer of } \\
\text { MOMOLAND }\end{array}$ \\
\hline 3 & $\begin{array}{l}\text { Lee } \\
\text { Dongmin } \\
\text { (Cha } \\
\text { Eunwoo) }\end{array}$ & $\begin{array}{l}\text { March 30, } \\
1997\end{array}$ & Korean & $\begin{array}{l}\text { Singer of } \\
\text { ASTRO }\end{array}$ \\
\hline 4 & $\begin{array}{l}\text { Lee Eunbi } \\
\text { (Sera) }\end{array}$ & - & Korean & Model, Host \\
\hline 5 & $\begin{array}{l}\text { Lee Hyebin } \\
\text { (Hyebin) }\end{array}$ & $\begin{array}{l}\text { January } \\
12,1996 \\
\end{array}$ & Korean & $\begin{array}{l}\text { Singer of } \\
\text { MOMOLAND }\end{array}$ \\
\hline 6 & $\begin{array}{l}\text { Lee } \\
\text { Joowon } \\
(\text { JooE })\end{array}$ & $\begin{array}{l}\text { August } \\
18,1999\end{array}$ & Korean & $\begin{array}{l}\text { Singer of } \\
\text { MOMOLAND }\end{array}$ \\
\hline 7 & $\begin{array}{l}\text { Lee } \\
\text { Seungri } \\
\text { (Nancy) }\end{array}$ & $\begin{array}{l}\text { April 13, } \\
2000\end{array}$ & $\begin{array}{l}\text { Korean- } \\
\text { American }\end{array}$ & $\begin{array}{l}\text { Singer of } \\
\text { MOMOLAND }\end{array}$ \\
\hline 8 & $\begin{array}{l}\text { Park } \\
\text { Jinwoo } \\
\text { (JinJin) }\end{array}$ & $\begin{array}{l}\text { March 15, } \\
1996\end{array}$ & Korean & $\begin{array}{l}\text { Singer of } \\
\text { ASTRO }\end{array}$ \\
\hline 9 & $\begin{array}{l}\text { Park } \\
\text { Minhyuk } \\
\text { (Rocky) }\end{array}$ & $\begin{array}{l}\text { February } \\
25,1999\end{array}$ & Korean & $\begin{array}{l}\text { Singer of } \\
\text { ASTRO }\end{array}$ \\
\hline 10 & $\begin{array}{l}\text { Song } \\
\text { Joongeun } \\
\text { (Jun) }\end{array}$ & $\begin{array}{l}\text { March 18, } \\
1980\end{array}$ & Korean & $\begin{array}{l}\text { Actor, } \\
\text { Comedian, } \\
\text { Host }\end{array}$ \\
\hline 11 & $\begin{array}{l}\text { Sung } \\
\text { Jiyeon } \\
\text { (Jane) }\end{array}$ & $\begin{array}{l}\text { December } \\
20,1997\end{array}$ & Korean & $\begin{array}{l}\text { Singer of } \\
\text { MOMOLAND }\end{array}$ \\
\hline 12 & $\begin{array}{l}\text { Yoon } \\
\text { Sanha } \\
\text { (Sanha) }\end{array}$ & $\begin{array}{l}\text { March 21, } \\
2000\end{array}$ & Korean & $\begin{array}{l}\text { Singer of } \\
\text { ASTRO }\end{array}$ \\
\hline
\end{tabular}

The hosts tests all of the singers listed in Figure 1 before they go to the K-Pop concert called K-Con. Jun, as the host, says that if they want to communicate with the audience in K-Con, speaking English is very important for them. As a result, the hosts test the singers' English-speaking abilities by asking the singers several questions. Based on the videos, 13 singers in total are assessed because ASTRO consists of six people, and MOMOLAND consists of seven people. However, one member of ASTRO and four members of MOMOLAND did not use any codeswitching and code-mixing during their dialog with the hosts, so they were automatically not included in the research. Consequently, only 8 out of the 13 singers became the participants, along with two hosts, Jun and Sera.

Seventy people participated in the survey, consisting of 35 females and 35 males who are 15-27 years old. Most participants are students or employees who have or do not have any interest in K-Pop. Out of 70 people, 42 of the participants are K-Pop fans, yet 42 out of the 70 people do not understand the Korean language at all. Out of the 70 people, the 28 who understand Korean are differentiated into two types: those who are fluent in Korean and those who are not. Interestingly, only 2 out of 28 people could understand and speak Korean fluently, whereas the rest were not fluent in Korean.

This research paper focuses on three videos on YouTube. The video of ASTRO is one full video of the same artist that is separated into two parts. These videos were chosen as the main focus of the research because the episode about ASTRO is the first episode of the show from 2016, while the MOMOLAND episode is the first episode from 2017. Table 2 below is the detailed information about the videos.

\begin{tabular}{|c|c|c|c|c|}
\hline No & Title & $\begin{array}{l}\text { YouTube } \\
\text { URL } \\
\end{array}$ & $\begin{array}{l}\text { Release } \\
\text { Date }\end{array}$ & Time \\
\hline 1 & $\begin{array}{l}\text { [KSTYLE TV] The } \\
\text { Immigration } \\
\text { ASTRO Part } 1\end{array}$ & $\begin{array}{l}\text { http://bit.ly/ } \\
\text { TheImmigra } \\
\text { tionASTRO } \\
\underline{1}\end{array}$ & $\begin{array}{l}\text { Septemb } \\
\text { er } 12, \\
2016\end{array}$ & 09:53 \\
\hline 2 & $\begin{array}{l}\text { [KSTYLE TV] The } \\
\text { Immigration } \\
\text { ASTRO Part } 2\end{array}$ & $\begin{array}{l}\text { http://bit.ly/ } \\
\text { TheImmigra } \\
\text { tionASTRO } \\
\underline{2}\end{array}$ & $\begin{array}{l}\text { Septemb } \\
\text { er 13, } \\
2016\end{array}$ & 04:08 \\
\hline 3 & $\begin{array}{l}\text { [KSTYLE TV] The } \\
\text { Immigration } \\
\text { MOMOLAND }\end{array}$ & $\begin{array}{l}\text { http://bit.ly/ } \\
\text { TheImmigra } \\
\text { tionMOMO } \\
\text { LAND }\end{array}$ & $\begin{array}{l}\text { January } \\
2,2017\end{array}$ & $10: 58$ \\
\hline
\end{tabular}

Furthermore, to analyze the perspective of the second type of participants, this research paper provided 24 with a questionnaire that covers the participants' personal information, language speaking ability, understanding of the English and Korean languages, and their opinion about code-switching and code-mixing between English and Korean, along with the language choice between English and Korean. The data were collected through Google Forms and filled out by various groups of people.

\section{Results and Discussion}

Each episode of the K-Style TV show The Immigration was analyzed, and particular transcripts are already in this paper to determine the influential factors that lead speakers to switch and mix their language between English and Korean. This research paper only focuses on particular transcripts because some of the members do not perform code-switching and code-mixing behaviors during their conversations. The conversations between the speakers are provided below.

\section{- $\quad$ ASTRO Episode 1}

\section{Excerpt 1}

Korean words are in bold, and translations are in italics.

Jun : Hey, what's that? What's that? 
MJ

: No my 사진(Picture).

Based on the utterances above, MJ mixes between English and Korean because he might forget the vocabulary for "picture" in English. According to DuRe Kim [9], the speaker may switch and mix languages when they cannot think of equivalent words in particular. Holmes [10] adds that people tend to switch and mix languages when they prefer to discuss a particular topic in a specific language. As a result, to clarify the context, he decides to use Korean in defining the picture so that the topic of the conversation remains clear.

\section{Excerpt 2}

Korean words are in bold, and translations are in italics.

Sera

: Stick out your tongue

Moonbin

: Tongue?

Sera

: Yeah, stick out your tongue

Moonbin : *opens and closes his mouth continuously*

Sera : 혀내래세요(Stick out your tongue.)

JinJin : 화나신것같애(She seems mad.)

Holmes [10] acknowledges that using codeswitching and code-mixing can be influenced by the solidarity between the speakers who are involved in the conversation. Solidarity itself manifests in several ways, such as sharing the same ethnicity. Based on the utterances above, Sera tends to switch from English to Korean because she may believe the participant will understand the command better if she uses Korean because they are both Korean. Moreover, JinJin tends to use Korean when he speaks with MJ because the solidarity between MJ and him as Koreans makes them more connected through speaking Korean rather than English.

\section{Excerpt 3}

Korean words are in bold, and translations are in italics.

$\begin{array}{ll}\text { Jun } & \text { : Oh, JooE is the winner! } \\ \text { JooE } & : * \text { looks happy and excited* } \\ \text { Jun } & : \text { Thank you } \\ \text { Nancy } & : \text { 예쁘다, 주이 (You look pretty, } \\ \text { JooE!) } & \\ \text { JooE } & : \text { Thank you! }\end{array}$

Based on the utterances above, Nancy speaks in Korean rather than English, even though she can speak English fluently because she is Korean-American. Although Jun and JooE speak to each other in English, she chooses Korean rather than English because she, as the member in the same group with JooE, shares solidarity with her as a Korean. Additionally, to show the closeness between JooE and her, she decides to maintain utterances in Korean rather than in English.

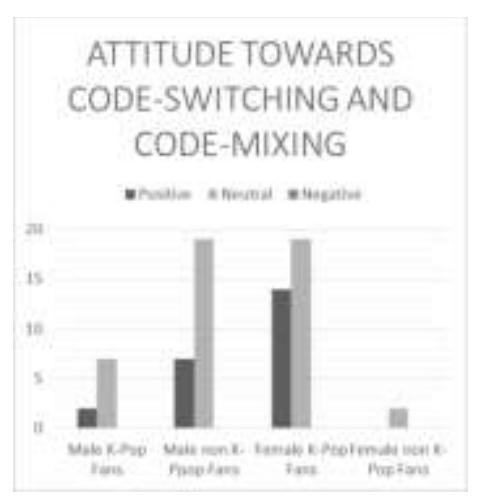

Fig. 1. Attitudes toward the code-switching and code-mixing phenomena

The chart shows that 26 males (19 K-Pop fans and 7 non-fans) and 21 females (19 fans and 2 non-fans) chose the neutral side. On the other hand, 9 males $(2$ fans and 7 non-fans) and 14 K-Pop female fans chose the positive attitude as their answer. Interestingly, no one from either sex answered the "negative" attitude as their choice. In short, both sexes mostly chose the neutral attitude toward the code-switching and codemixing phenomena.

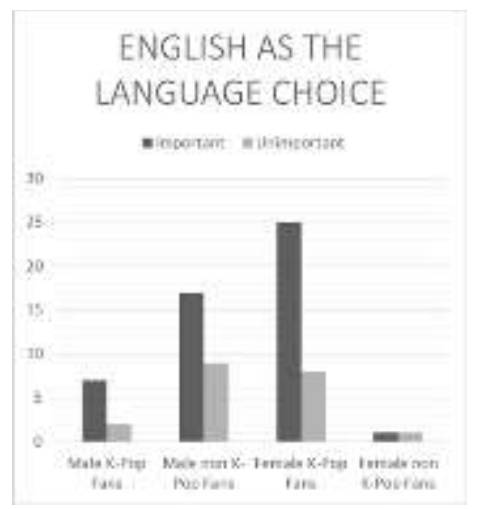

Fig. 2. The importance of English as a language choice

Interestingly, it shows that 24 males ( 7 fans and 17 non-fans) chose English as an essential language choice, as well as 26 females (25 fans and 1 non-fan). On the other hand, 11 males (2 fans and 9 non-fans) did not choose English as an important language choice, which was higher than the number of females, as only nine females (eight fans and one non-fan) answered this way. As a result, both sexes mostly stated that English is essential as the language choice for K-Pop idols.

\section{A. Solidarity and Topics as the Most Dominant Influential Factors}

According to the findings, topics and solidarity became the dominant factors that influence K-Pop idols to perform code-switching and code-mixing. Stylianou-Panayi [2] states that these phenomena are not only unavoidable but are also necessary. When the speakers switch and mix languages from English to Korean, it makes the conversation remain ongoing, although the idols cannot find equivalent words in English. Du-Re Kim [9] mentions that it is common for Korean speakers to switch and mix languages because they want to help their interlocutors 
comprehend their meaning during conversations. Excerpt 1 portrays the situation above. Additionally, K-Pop idols tend to switch and mix languages according to the topic, which becomes a way to save themselves in front of their interlocutor. Al Heeti and Al Abdely [11] mention that this can boost their confidence during the conversation to avoid signs of a lack of knowledge and experience. Therefore, rather than mumbling nonsense, K-Pop idols choose to mix and switch languages to maintain the conversation. Excerpts 5 and 6 portray the situation above.

Next, solidarity became a dominant factor because it signals that they want to maintain and reinforce their Korean identity. For instance, in excerpt 3, Jun gives a sign to Sanha that he actually can speak Korean by replying to Sanha's utterances in Korean. Sanha, who is amazed by the way Jun replies to him in Korean, ends up complimenting Jun as a tool to maintain the solidarity among them as Koreans. Furthermore, Shin [12] mentions that the way Korean people switch languages from English to Korean can be a tool to express respect, especially to elders or seniors. Additionally, the group membership among the K-Pop idols signals solidarity with each other, which leads to switching and mixing languages they are comfortable with. Shim [13] mentions that the closer the relationship is between the Korean speakers, the more they use the Korean language.

\section{B. Diversity in the Perspective of Viewers Toward the Use of English}

The survey analysis shows that the participants, who were distinguished into four categories, had similarities and differences in answering the questions from the survey. Referring to Angelica-Nicoleta and $\mathrm{Cuz}$ [14], human behavior is distinguished into a biological and a cultural factors, which connects to the reflection of communication style within each sex group. Although the differences should be complementary, there is still binary thinking within each sex group that may reflect their particular tastes. Through the survey, it shows that most of the female participants are K-Pop fans, whereas most of the male participants are non-K-Pop fans. This sense of belonging to K-Pop fandom led to that K-Pop female fans mostly being able to understand the Korean language more than the male K-Pop and non-K-Pop fans.

Based on the survey, the way male K-Pop and nonK-Pop fans perceived the ability of K-Pop idols to speak English was quite different from the females. On the one hand, both male K-Pop and non-K-Pop fans thought that K-Pop idols' fluency in English makes them look smarter and better than those who cannot speak English fluently. On the other hand, both female K-Pop and non-K-Pop fans perceived this was as something useful for them because they can better understand K-Pop idols' utterances. The answer from the females reflects the strategy of K-Pop idols in this broadcast, which is to attract more fans using English, which has been mentioned by the host. Kim [15] states that the multicultural method, as a tool of communication across different cultures and social groups in K-Pop production, can help K-Pop idols to popularize themselves in the global market. In other words, the intention that The Immigration wants to deliver is well received by the female K-Pop and nonK-Pop fans.

Moreover, opinions about the importance of English for K-Pop idols were also diverse. Male KPop and non-K-Pop fans tended to view the Englishspeaking abilities of K-Pop idols as a useful tool for better promotion, and female non-K-Pop fans supported this answer. Meanwhile, female K-Pop fans perceived this as a better tool to communicate with the fans. This result might be similar to the perception that it can be beneficial for K-Pop idols to speak in English. The thing that differed within each sex group was that male K-Pop and non-K-Pop fans (also female non-K-Pop fans) saw this from the K-Pop idols' perspective more than the female K-Pop fans, who saw this from the fans' perspective. This opinion leads to a diversity in the impact of K-Pop idols' fluency in English for the fans.

\section{Conclusion}

This paper investigates the reason behind the occurrence of code-switching and code-mixing in the dialog of K-Pop idols on a variety show on K-Style TV called The Immigration. This broadcast became the topic of research because K-Pop has been well known worldwide for several decades, resulting in the expectation that K-Pop idols be able to speak English. Several K-Pop idols have successfully managed to interact with the host of the show using English rather than Korean. However, some K-Pop idols who are not familiar with English tend to perform code-switching and code-mixing. This study showed that solidarity and choice of topic were the most common reasons $\mathrm{K}$ Pop idols tend to switch and mix languages. These reasons may have emerged because K-Pop idols share the same nationality, and they are more comfortable interacting using the Korean language than English. Moreover, they tend to use Korean when they want to emphasize a topic that may be more suitable in Korean.

Lastly, the result of the survey may be helpful for further research regarding people's opinions toward code-switching and code-mixing for celebrities, especially K-Pop idols who are not native English speakers. However, since this research paper only provides the answers from 70 people who consisted of more female K-Pop fans than male K-Pop fans, future research may focus more on the differentiation between male and female opinions with a similar composition of personal backgrounds. For instance, future research can focus on a balanced composition in the level of proficiency of English between both sex groups. Additionally, future research may look at the same range of K-Pop fans for both sex groups. A more comprehensive range of participants may provide a more precise idea regarding this matter to improve results in the future. 


\section{Acknowledgments}

We would like to thank Universitas Indonesia for providing the academic platform for us to conduct our research and share the findings in an international conference at the Faculty of Humanities, Universitas Indonesia.

\section{References}

[1] Luthfiyani, F. (2014). Code-switching and Code-Mixing on Korean Television Music Show: After School Club. Jakarta: Universitas Islam Negeri Syarif Hidayatullah.

[2] Stylianou-Panayi, N. (2015). Code-Switching in an EFL Environment. Linguistics and Literature Studies, 259-263.

[3] Owen, D. (n.d.). What Languages Do They Speak in South Korea? Retrieved from Discover Your Ultimate Gap Year Experience: https://www.gapyear.com/articles/traveltips/south-korea-languages

[4] K-Con About. (n.d.). Retrieved from M-Wave: https://www.mwave.me/en/kcon/about

[5] ASTRO members profile. (n.d.). Retrieved from KProfiles: https://kprofiles.com/astro-members-profile/

[6] Eunbi Lee. (n.d.). Retrieved from Star Now: https://www.starnow.com/eunbilee
[7] MOMOLAND members profile. (n.d.). Retrieved from KProfiles: https://kprofiles.com/momoland-membersprofile/

[8] Song Joon-Geun. (n.d.). Retrieved from Han Cinema: https://www.hancinema.net/korean_Song_Joon-geun.php

[9] Kim, D.-R. (2012). Functions of Code-switching in Korean EFL Learner's Conversation. Language Research 297-318.

[10] Holmes, J. (2013). An Introduction to Sociolinguistics (4th edition). New York: Routledge.

[11] Al Heeti, N. \& Al Abdely, A. (2016). Types and Functions of Code-switching in the English language used by Iraqi doctors in Formal Settings. International Journal of Advanced Research and Review, 10-18.

[12] Shin, S. (2010). The functions of Code-switching in a Korean Sunday School. Heritage Language Journal, 91116.

[13] Shim, J. (2014). Bilingual Speakers of English and Korean and Code Switching Practice. International Journal of Education, 21-48.

[14] Angelica, N., \& Cuza, A. I. (2015). Culture and Gender Role Differences. Cross-Cultural Management Journal, 3135.

[15] Kim, A. (2017). Korean Popular Music (K-Pop), Youth Fan Culture, and Art Education Curriculum. (Master's thesis). Retrieved from https://scholarcommons.sc.edu/etd/4368 